Assesssment of Effectiveness of

Geologic Isolation Systems

\title{
Variable Thickness Transient Ground-Water Flow Model \\ Volume 1. Formulation
}

\author{
A. E. Reisenauer
}

December 1979

Prepared for the

Office of Nuclear Waste Isolation

under its Contract with the

U.S. Department of Energy

Pacific Northwest Laboratory

Operated for the U.S. Department of Energy

by Battelle Memorial Institute 


\title{
NOTICE
}

This report was prepared as an account of work sponsored by the United States Covernment. Neither the United States nor the Department of Energy, nor any of their employees, nor any of their contractors, subcontractors, or their employees, makes any warranty, express or implied, or assumes any legal liability or responsibility for the accuracy, completeness or usefulness of any information, apparatus, product or process disclosed, or represents that its use would not infringe privately owned rights.

The views, opinions and conclusions contained in this report are those of the contractor and do not necessarily represent those of the United States Government or the United States Department of Energy.

\author{
PACIFIC NORTHWEST LABORATORY \\ operated by \\ BATTELLE \\ for the \\ UNITED STATES DEPARTMENT OF ENERGY \\ Under Contract EY-76-C-06-1830
}

\begin{tabular}{|c|c|}
\hline \multicolumn{2}{|c|}{$\begin{array}{c}\text { Printed in the United States of America } \\
\text { Available from } \\
\text { National Technical Information Service } \\
\text { United States Department of Commerce } \\
5285 \text { Port Royal Road } \\
\text { Springfield, Virginia } 22151\end{array}$} \\
\hline ce: Printed Copy & _; Microfiche $\$ 3.00$ \\
\hline -Pages & $\begin{array}{c}\text { NTIS } \\
\text { Sefling Price }\end{array}$ \\
\hline $001-025$ & $\$ 4.00$ \\
\hline $026-050$ & $\$ 4.50$ \\
\hline $051-075$ & $\$ 5.25$ \\
\hline $076-100$ & $\$ 6.00$ \\
\hline $107-125$ & $\$ 6.50$ \\
\hline $126-150$ & 57.25 \\
\hline $151-175$ & $\$ 8.00$ \\
\hline $176-200$ & $\$ 9.00$ \\
\hline $201-225$ & $\$ 9.25$ \\
\hline $226-250$ & $\$ 9.50$ \\
\hline $257-275$ & $\$ 10.75$ \\
\hline $276-300$ & $\$ 11.00$ \\
\hline
\end{tabular}


VOLUME 1. FORMULATION

\author{
A. E. Reisenauer
}

December 1979

Prepared for the

Office of Nuclear Waste Isolation under its Contract with the

U.S. Department of Energy

Pacific Northwest Laboratory

Richland, Washington 99352 


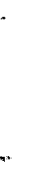




\section{FOREWORD}

The. Assessment of Effectiveness of Geologic Isolation Systems (AEGIS) Program is developing and applying the methodology for assessing the far-field, long-term post-closure safety of deep geologic nuclear waste repositories. AEGIS is being performed by Pacific Northwest Laboratory (PNL) under contract with the Office of Nuclear Waste Isolation (ONWI) for the Department of Energy (DOE). One task with in AEGIS is the development of methodology for analys is of the consequences (water pathway) from loss of repository containment as defined by various release scenarios.

Analysis of the long-term, far-field consequences of release scenarios requires the application of numerical codes which simulate the hydrologic systems, model the transport of released radionuclides through the hydrologic systems to the biosphere, and, where applicable, assess the radiological dose to humans.

Essentially three modeling technologies are involved in assessing the water pathway release consequence. These models are: 1) hydrologic models that define the groundwater flow field and provide water flow paths and travel times, 2) transport models that describe the movement and concentrations of the radionuclides in the flow field, and 3 ) dose models that determine the resultant radiation doses to individuals and/or populations. Figure $i$ is a schematic flow diagram for the release consequence analysis.

The various input parameters required in the analysis are compiled in data systems. The data are organized and prepared by various input subroutines for use by the hydrologic and transport codes. The hydrologic models simulate the groundwater flow systems and provide water flow directions, rates, and velocities as inputs to the transport models. Outputs from the transport models are basically graphs of radionuclide concentration in the groundwater plotted against time. After dilution in the receiving surfacewater body (e.g., lake, river, bay), these data are the input source terms for the dose models, if dose assessments are required. The dose models calculate radiation dose to individuals and populations. 


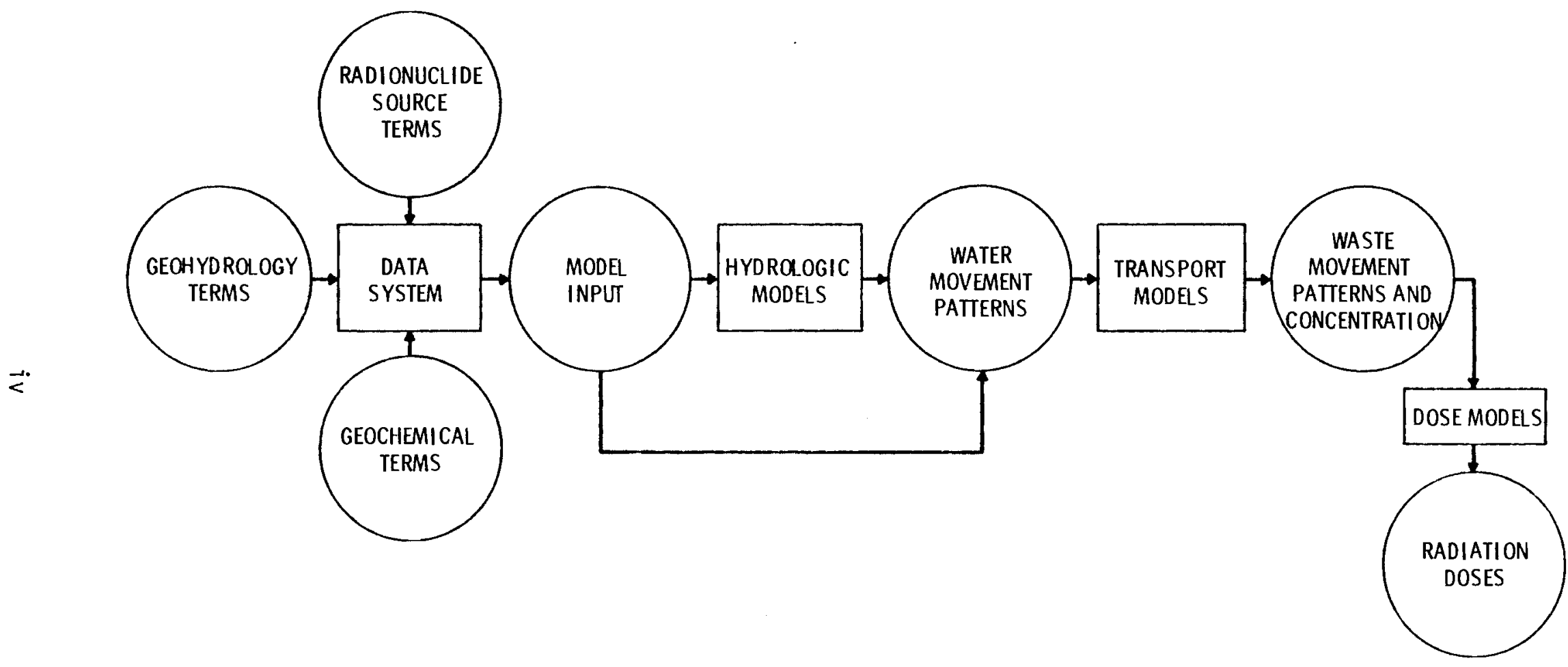

FIGURE i. Schematic Diagram of Consequence Analys is 
Hydrologic and transport models are available at several levels of complexity or sophistication. Model selection and use are determined by the quantity and quality of input data. Model development under AEGIS and related programs provides three levels of hydrologic models, two levels of transport models, and one level of dose models (with several separate models). The models and data systems are documented as follows:

- HYDROLOGIC MODELS:

PNL-3162 PATHS Groundwater Hydrologic Model - first level (simplest) idealized hybrid analytical/numerical model for twodimensional, saturated groundwater flow and single component transport; homogeneous geology.

PNL-3160 VTT (Variable Thickness Transient) Groundwater Hydrologic Model - second level (intermediate complexity) twodimensional saturated groundwater flow, Boussinesq approximation, finite difference approach; two-dimensional (quasi three-dimensional) multiaquifer capability; heterogeneous geology.

PNL-2939 FE3DGW (Finite Element, Three-Dimensional Groundwater Hydrologic Model - third level (high complexity) threedimensional, finite element approach (Galerkin formulation) for saturated groundwater flow; heterogeneous geology.

- TRANSPORT MODELS:

PNL-2970 GETOUT Transport Model - first level one-dimensional analytical solution considering radioactive chain decay with capability for only simple release and hydrologic functions; single speciation, constant flow rate, dispersion and sorption three-member straight delay chains.

PNL-3179 MMT (Multicomponent Mass Transport) Mode1 - second leve1, one-dimensional numerical, discrete parcel random walk (DPRW) algorithm; chain decay, single speciation, equilibrium sorption, time-variant leach rate and dispersion, n-membered straight or branched decay chains. 
- DOSE MODELS:

PNL-3180 ARRRG - drinking water, external exposure to aquatic food, water and shorelines, and FOOD - terrestrial food.

PNL-3209 PABLM - Combination of ARRRG and FOOD with additional features related to chronic releases.

BNWL-B-264 KRONIC - chronic external dose from air pathways.

BNWL-B-351 SUBDOSA - acute external dose from air pathways.

BNWL-B-389 DACRIN - chronic or acute inhalation dose from air pathways.

- DATA SYSTEMS:

PNL-3139 SIRS (Sorption Information Retrieval System) - storage and retrieval system for experimental data on sorption/desorption analyses for a wide variety of radionuclides, groundwater compositions, and rocks and minerals.

PNL-3161 CIRMIS (Comprehensive Information Retrieval and Model Input Sequence) Data System - storage and retrieval system for model input and output data, including graphical interpretation and display.

This is the first of 3 volumes of the description of the VTT hydrologic mode 1 .

Return of the form on the last page of this report is required in order to remain on the Distribution List for future revisions of the model. 


\section{ACKNOWLEDGMENT}

This research was supported by the Waste Isolation Safety Assessment Program being conducted by Pac if ic Northwest Laboratory. This program was sponsored by the Office of Nuclear Waste Isolation, managed by Battelle Memorial Institute for the Department of Energy under Contract EY-76-C-06-1830. On 1 October 1979, WISAP became the Assessment of Effectiveness of Geologic Isolation Systems (AEGIS) Program and the Waste/Rock Interactions Technology (WRIT) Program. This report was issued by AEGIS. 
m....

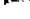

; . 


\section{CONTENTS}

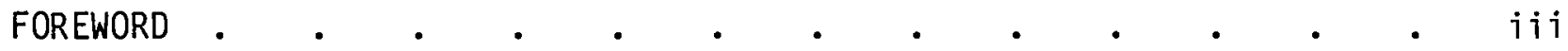

ACKNOWLEDGMENT

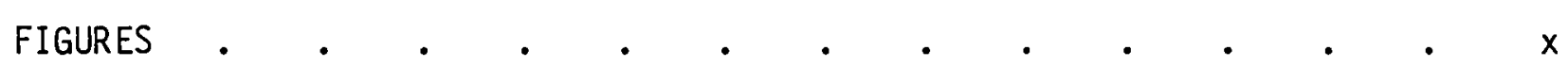

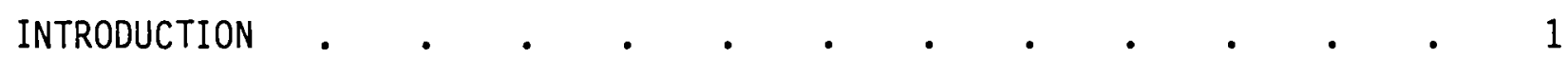

MATHEMATICAL FORMULATION FOR THE VARIABLE THICKNESS

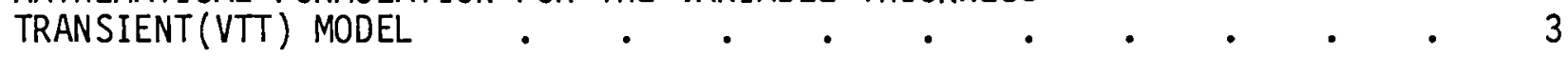

ASSUMPTIONS $\quad$ • $\quad$ • $\quad$ •

SPECIFIC DATA REQUIREMENTS FOR THE PHYSICAL PARAMETERS • • • • • 9

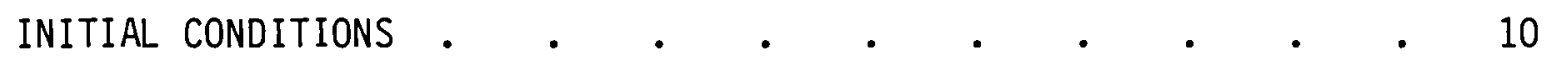

BOUNDARY CONDITIONS •

RECHARGE-DISCHARGE LOCATIONS AND RATES • • • • • • • • • 12

NUMERICAL FORMULATION OF SYSTEM OF EQUATIONS •

BOUNDARY DEFINITIONS $\quad$ • $\quad$ •

SOLUTION TECHNIQUES

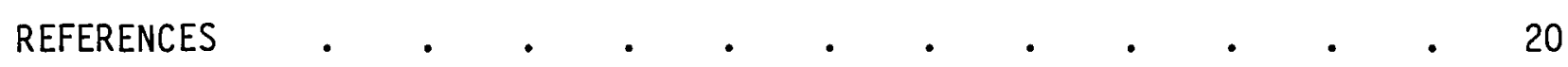

VOLUME 2 - VARIABLE THICKNESS TRANSIENT GROUND-WATER FLOW MODEL USERS' MANUAL

VOLUME 3 - PROGRAM LISTINGS 


\section{FIGURES}

i Schematic Diagram of Consequence Analysis . . . . . . . . . iv

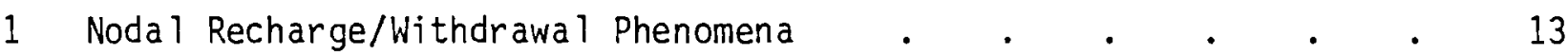

2 The Finite Difference Grid with the Nodal Numbering System • • 14

3 Schematic Showing Shapes and Rotation of Available Boundary Conditions Types . 


\section{INTRODUCTION}

Any modeling effort requires some simplifying assumptions to bridge the gap between reality and our current knowledge or understanding of the system being modeled and practicability. In most modeling fields certain basic simplifying assumptions are routinely accepted, whereas others require justification based on data gathered and observations made on the real-world system being modeled. In the set of equations we will write in this section, a large amount of the modeling effort and associated assumptions have already been made (cf., Bear et al. 1972). The set of assumptions and modeling effort discussed in Chapter 4 of Bear's report takes us from the complex world of porous media particles and the associated tortuous flow paths for ground water to the regime of representative elementary volumes and the fluid flow continuum. These assumptions are generally accepted in the field of ground-water hydrology and are complex enough that they will not be presented here. The equations we write to describe an aquifer system will be for a fluid flow continuum in porous media. However, it is not sufficient for a mathematical model to be based on a sound set of equations which describe the physical system. The model must also be based on technically sound hydrologic information and reasonable simplifying assumptions regarding these hydrologic interpretations. The advent of high-speed digital computers has paved the way for making computer simulation of complex ground-water systems a practical reality.

The digital computer model is designed to simulate the hydraulic-head response to natural and man-made aquifer stresses in a multi-layered twodimensional aquifer system. The real ground-water system is, of course, a three-dimensional system, including precipitation percolating from the surface through unsaturated soil into the uppermost aquifer. In some cases along rivers or streams or at the base of lakes and ponds, the aquifers are discharging into or being recharged from these surface-water bodies. These conditions formulate one type of boundary condition for our mathematical model. The units we call separate aquifers are really water saturated layers in the soil and rock matrix which make up the earth's crust. These units are 
generally more permeable than the geologic units directly below them and sometimes above. As a result, the water in an aquifer tends to flow in a horizontal direction along the bedding plane of the more permeable geologic formation since the resistance to flow is less. The less permeable (aquitard) or sometimes impermeable (aquiclude) layers below and sometimes above the aquifer materials retard or completely block the vertical flow. These less permeable layers are designated as the base and top of the aquifer unit. When a more permeable layer exists below the upper aquifer unit's base, another aquifer may exist. When the aquitard material between aquifers is somewhat permeable, there can be water transfer between the aquifer units, depending on the water potential or pressure in the units. For most regional ground-water models which are currently being used, a simplifying assumption is made which transforms this three-dimensional system to a layered two-dimensional system with interaquifer transfer via a potential-driven leakage term. The mathematical model which utilizes this set of simplifying assumptions is the multi-aquifer formulation of the Boussinesq equations. 


\section{MATHEMATICAL FORMULATION FOR THE VARIABLE}

THICKNESS TRANSIENT (VTT) MODEL

Often an exact solution of the general, three-dimensional, saturated flow equation and free-surface boundary condition is not required to obtain useful results. VTT utilizes the Dupuit-Forchheimer or Boussinesq approximate method, which assumes a simplified, two-dimensional horizontal view of the ground-water system. This allows the free-surface boundary condition and the flow equation to be combined into a single equation amenable to practical numerical solution techniques. For simplicity we will refer to this method as the Boussinesq Flow Model.

Let $x, y, z$ be the coordinates of a fluid particle, then $d x / d t, d y / d t$ and $\mathrm{dz} / \mathrm{dt}$ are the components of "pore velocity," and the Darcian seepage velocities are:

$$
\begin{aligned}
& v_{x}=n_{e} \frac{d x}{d t} \\
& v_{y}=n_{e} \frac{d y}{d t} \\
& v_{z}=n_{e} \frac{d z}{d t}
\end{aligned}
$$

where:

$$
n_{e}=\text { effective porosity. }
$$

Now, if we let $z=h(x, y, t)$ represent the coordinate of the free surface and formally differentiate with respect to time, we have:

$$
\frac{\partial z}{\partial t}=\frac{\partial h}{\partial x} \frac{d x}{d t}+\frac{\partial h}{\partial y} \frac{d y}{d t}+\frac{\partial h}{\partial t}
$$

Substituting the Darcian velocities and rearranging we have: 


$$
n_{e} \frac{\partial h}{\partial t}+v_{x} \frac{\partial h}{\partial x}+v_{y} \frac{\partial h}{\partial y}-v_{z}(h)=0
$$

The Dupuit assumptions used in this model may be simply stated as: $\phi(x, y, z, t) \approx \phi(x, y, \bar{z}, t)$ where $\bar{z}=$ average height of the water particles above reference datum. This is equivalent to stating that flow is essentially horizontal, so that vertical flow components can be neglected and that the slope of the water table surface is slight $\left(<5^{\circ}\right)$. If we assume an incompressible fluid and full saturation, then our equation of continuity written in terms of Darcian velocities becomes:

$$
\frac{\partial V_{x}}{\partial x}+\frac{\partial V_{y}}{\partial y}+\frac{\partial V_{z}}{\partial z}=0
$$

Since we wish to average in the $z$ direction, we must integrate this equation from the base of the aquifer to the free surface or:

$$
\left.v_{z}\right|_{z=0} ^{z=h}=v_{z}(h)=\frac{\partial V_{x}}{\partial x}+\frac{\partial V_{y}}{\partial y}
$$

Defining $\phi$ as the head in units of length, $\phi=P / \rho g+z$, the value of $\phi$ is equal to $z$ at the free surface, since $P=0$ at that point. Using this result a long with the first Dupuit assumption and our earlier equation $(z=h(x, y$, $t$ ), we have:

$$
h(x, y, t)=\phi(x, t, \bar{z}, t)
$$

From this result Darcy's law can be rewritten as:

$$
v_{x}=-\bar{K} \frac{\partial h}{\partial x}
$$




$$
v_{y}=-\bar{K} \frac{\partial h}{\partial y}
$$

where:

$$
\begin{aligned}
K(x, y)= & \text { vertically averaged value of hydraulic conductivity at } \\
& \text { location }(x, y)
\end{aligned}
$$

Substituting Equations 9 and 10 into 5 we have:

$$
n_{e} \frac{\partial h}{\partial t}-\bar{k}\left[\left(\frac{\partial h}{\partial x}\right)^{2}+\left(\frac{\partial h}{\partial y}\right)^{2}\right]-v_{z}(h)=0
$$

Now replacing $v_{z}(h)$ with the expression obtained from substituting the results of Equations 9 and 10 into Equation 11.

$$
n_{e} \frac{\partial h}{\partial t}-\bar{K}\left[\left(\frac{\partial h}{\partial x}\right)^{2}+\left(\frac{\partial h}{\partial y}\right)^{2}\right]-h \frac{\partial}{\partial x}\left[\left(\frac{\bar{K} \partial h}{\partial x}\right)+\frac{\partial}{\partial y}\left(\frac{\bar{K} \partial h}{\partial y}\right)\right]=0
$$

Rearranging Equation 12 yields:

$$
n_{e} \frac{\partial h}{\partial t}-\frac{\partial}{\partial x}\left(\frac{\bar{K} h \partial h}{\partial x}\right)-\frac{\partial}{\partial y}\left(\frac{\bar{K} h \partial h}{\partial y}\right)=0
$$

or in gradient vector notation

$$
n_{e} \frac{\partial h}{\partial t}-\nabla \cdot(\bar{K} h \nabla h)=0
$$

Equation 13 is termed the Boussinesq equation. To this point for simplicity of development we did not include source terms and have assumed that the aquifer base elevation is the zero reference elevation. To expand Equations 13 or 14 to handle an aquifer with varying bottom elevation $h_{b}(x, y)$, and to include source/sink or accretion terms, we must do the following: 
- assume that the bottom slope is slight, as we did for the free-surface slope;

- replace $h$ in Equations 13 or 14 , which was a result of integrating from $z$ $=0$ to $z=h$ by $h-h_{b}$, since our integration is now done from $z=h_{b}$ to $z=h$;

- add the accretion term, $N$.

The resulting equation is the Boussinesq equation for unsteady flow:

$$
\bar{n}_{e} \frac{h}{t}=\nabla \cdot \bar{k}\left(h-h_{b}\right) \nabla h+N
$$

where:

$$
\begin{aligned}
\bar{n}_{e}(x, y)= & \text { vertical average of the effective porosity of the } \\
& \text { aquifer (dimensionless) } \\
h(x, y)= & \text { elevation of the free surface from some reference } \\
& \text { elevation }(L) \\
h_{b}(x, y)= & \text { elevation of the aquifer bottom from the reference } \\
& \text { elevation (L) } \\
N(x, y)= & \text { accretion rate }\left(L T^{-1}\right) \\
R(x, y)= & \text { vertically averaged value for hydraulic conductivity at } \\
& \text { point }(x, y)\left(L T^{-1}\right)
\end{aligned}
$$




\section{ASSUMPTIONS}

The basic assumptions of the Boussinesq flow model for describing saturated unconfined flow are:

- Flow is by an incompressible fluid that saturates a rigid, porous soil matrix.

- Compressibility effects of the fluid and soil matrix can be neglected under conditions of unconfined or free-surface flow; however, they are incorporated into the storage term for confined flow.

- Hydraulic conductivity and effective porosity can be represented by the vertical average values and are isotropic but inhomogeneous throughout the region.

- The free-surface slope and the aquifer bottom slope are both assumed to be slight $\left(<5^{\circ}\right)$.

- Vertical velocities are assumed to be small and therefore can be neglected.

- Coefficient distributions and dependent variables are assumed continuous over the simulation region.

- Flow in the capillary fringe is neglected.

- Seepage surfaces cannot be handled and are therefore neglected.

The Boussinesq formulation as presented above allows one to approximate the elevation of the free surface in a single unconfined aquifer at every ( $x$, y) location. Many times in a real system, one wishes to simulate a multi-aquifer system, in which one or more of the aquifers are confined, although these confined aquifers may be unconfined in some places. Also there may be transfer of water between the aquifers. This kind of a multi-aquifer system can be handled by a multi-aquifer set of Boussinesq equations with potential driven interaquifer tranfer or leakage terms. For a multilayered system the equations would be: 


$$
\begin{aligned}
S^{i} \frac{\partial h^{i}}{\partial t}= & \frac{\partial}{\partial x}\left(T^{i} \frac{\partial h^{i}}{\partial x}\right)+\frac{\partial}{\partial y}\left(T^{i} \frac{\partial h^{i}}{\partial y}\right)+N^{i}+\sum_{j=1}^{-1} c_{j \rightarrow i}\left(h^{j}-h^{i}\right) \\
& +\sum_{j=i+1} c_{j \rightarrow i}\left(h^{j}-h^{i}\right)
\end{aligned}
$$

where:

$$
\begin{aligned}
i= & 1,2, \ldots n \\
n= & \text { number of layers } \\
c_{i \rightarrow j}=c_{j \rightarrow i}= & \text { interaquifer transfer coefficient between layer } i \\
& \text { and } j \\
S^{i}= & n_{e}^{i} \text { for unconfined system or storage coefficient for } \\
& \quad \text { the confined system } \\
\mathrm{T}^{i}= & \text { transmissivity for a confined system is } k^{i} \text { times the } \\
& \quad \text { thickness of aquifer or } k^{i}\left(h^{i}-h_{j}\right) \text { for an } \\
& \text { unconfined or water table aquifer } \\
N^{i}= & \text { the flux or stress term applied to layer } i
\end{aligned}
$$

As with any mathematical model there are specific data requirements, boundary conditions, and initial conditions which must be specified. Equation 16 as presented is the transient equation. When the left-hand side of Equation 16 is replaced by zero, the steady-state equation results. As mentioned previously, the transient equation allows one to investigate the effects of seasonal fluctuations and rates of change, whereas the steady-state equation allows one to investigate the ultimate effect of any water use policy. Use of the transient model requires that the storage coefficient distribution be known, whereas the steady-state model does not require this distribution. 
SPECIFIC DATA REQUIREMENTS FOR THE PHYSICAL PARAMETERS

The following are the specific data requirements:

- Hydraulic conductivity $(K=k / \mu$, where $k=$ intrinsic permeability and $\mu=$ fluid viscosity); transmissivity ( $T=K b$, where $b=$ saturated thickness of the aquifer material).

The Boussinesq flow model requires as an input the saturated hydraulic conductivity or transmissivity distribution throughout the region being modeled and for each aquifer being modeled. The values required by the Boussinesq model must represent the vertical average of the $K$ or $T$ of the saturated thickness of the aquifer.

Hydraulic conductivity or transmissivity reflects the ability of the rock and soil matrix to allow water transmission. The $K$ or $T$ distribution is usually determined via appropriately conducted pumping tests, where the we 11 is fully penetrating and perforated throughout saturated aquifer material. Data from these type of field measurements are expensive to obtain, and therefore the $K$ or $T$ distribution is extrapolated from a small number of these measurements. This initial distribution is further modified during the model calibration phase to obtain better agreement between model-predicted potentials and observed potentials. Hydraulic conductivity can also be estimated from laboratory studies of aquifer material samples, lithologic data and inverse mathematical modeling methods.

- Storage coefficient (or effective porosity $n_{e}$ and vertical compressibility of the soil matrix $[\alpha]$ ).

The transient form of the Boussinesq equation requires the distribution of the vertical averaged value of the storage coefficient for each aquifer throughout the region being modeled. This parameter controls the rate at which the water and disturbances in the potential surface propogate throughout the groundwater system. In the case of an unconfined system, the storage coefficient is dominated by the effective porosity of the aquifers soil matrix. 
Contributions to the storage coefficient based on soil matrix compressibility and water compressibility are ignored. In the case of confined systems, the storage is a function of the aquifer soil matrix compressibility $(\alpha)$, effective porosity $\left(n_{e}\right)$, with storage $=\operatorname{pg}(\alpha+$ $\left.n_{e}^{\beta}\right)$.

Storage or effective porosity can be determined via pumping tests with observations wells, lithologic data from core samples, and laboratory or in situ measurement techniques. In addition, storage coefficients can be determined during model calibration when adequate transient data on potentials exist.

- Interaquifer transfer coefficients $\left(C_{j+i}\right)$

The multiaquifer Boussinesq Flow Model requires an interaquifer transfer coefficient, which is a measure of the hydraulic interconnection between aquifer systems. This value is a function of the thickness and hydraulic conductivity of the aquitard separating the aquifer systems. This value must be determined at each $(x, y)$ location where an aquitard exists between the aquifers. This value arises naturally in the other three dimensional formulations in the form of $(X, Y, Z)$ hydraulic conductivity distributions. It is generally obtained via model calibration of inverse modeling techniques.

\section{INITIAL CONDITIONS}

The Boussinesq flow model requires initial conditions. The Boussinesq flow model requires one average potential value for each aquifer for each ( $x$, y) grid location throughtout the region being modeled.

\section{BOUNDARY CONDITIONS}

Like all mathematical models, the Boussinesq model requires that boundary conditions be specified. Boundary conditions are difficult to formulate and result from interpretations of potential data, we 11 logs, and lithologic data. The physical extent of the aquifer and or aquifers are defined. This includes a geometrical description of the positions in space of the aquifer materials such as: 
- the lateral boundaries of the aquifer or aquifer systems

- contour maps of the base and top of the aquifer or aquifer systems. Along each of the lateral boundaries, the conditions which describe the physical situation which exists must be determined. These include:

- Lateral Flow Boundary

This results from not extending the model to the geologic boundaries of the aquifer or aquifer systems. At these boundaries the rate that water is flowing into or out of the aquifer of aquifer system must be specified.

- No Flow Boundaries

These occur when the model has been extended to the geologic boundaries of the aquifer where the aquifer materials and impermeable barriers meet.

- Held or Time Varying Potential Boundaries

These occur at large lakes and rivers, where the saturated aquifer materials are in contact with large bodies of water whose water surface elevations are essentially unaffected by aquifer potentials. 


\section{RECHARGE - DISCHARGE LOCATIONS AND RATES}

Typically when modeling an aquifer system which extends to the major recharge areas of the aquifer, the following types of data are used to est imate aquifer recharge:

- precipitation records

- surface slope

- temperature record

- surface soil types

- vegetation cover and land use

- evapotranspiration data.

Man-made recharge or discharge must also be accounted for by determining:

- location of pumping and recharge wells

- use of water and infiltration mechanisms (e.g., septic tanks, irrigation infiltrations, settling ponds).

Along flow boundaries where the area being modeled does not extend to geologic boundaries, the flow across this boundary must be determined via pump test and geologic studies conducted along this boundary.

Figure 1 illustrates graphically the phenomena which must be considered in calculating the distribution of aquifer stress values throughout the region being modeled. 


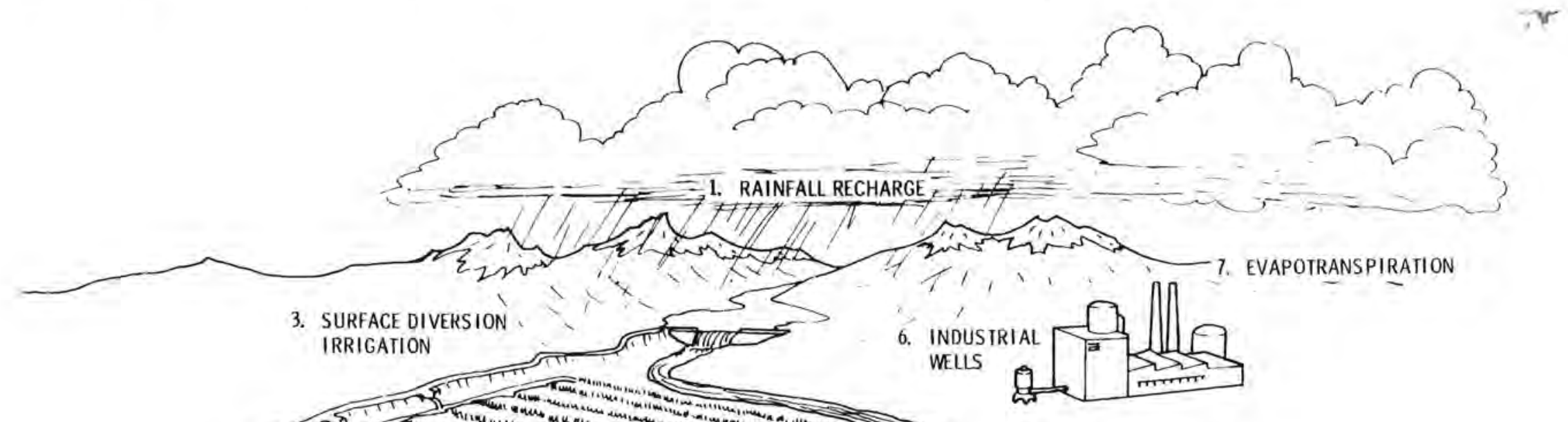

$\vec{\omega}$

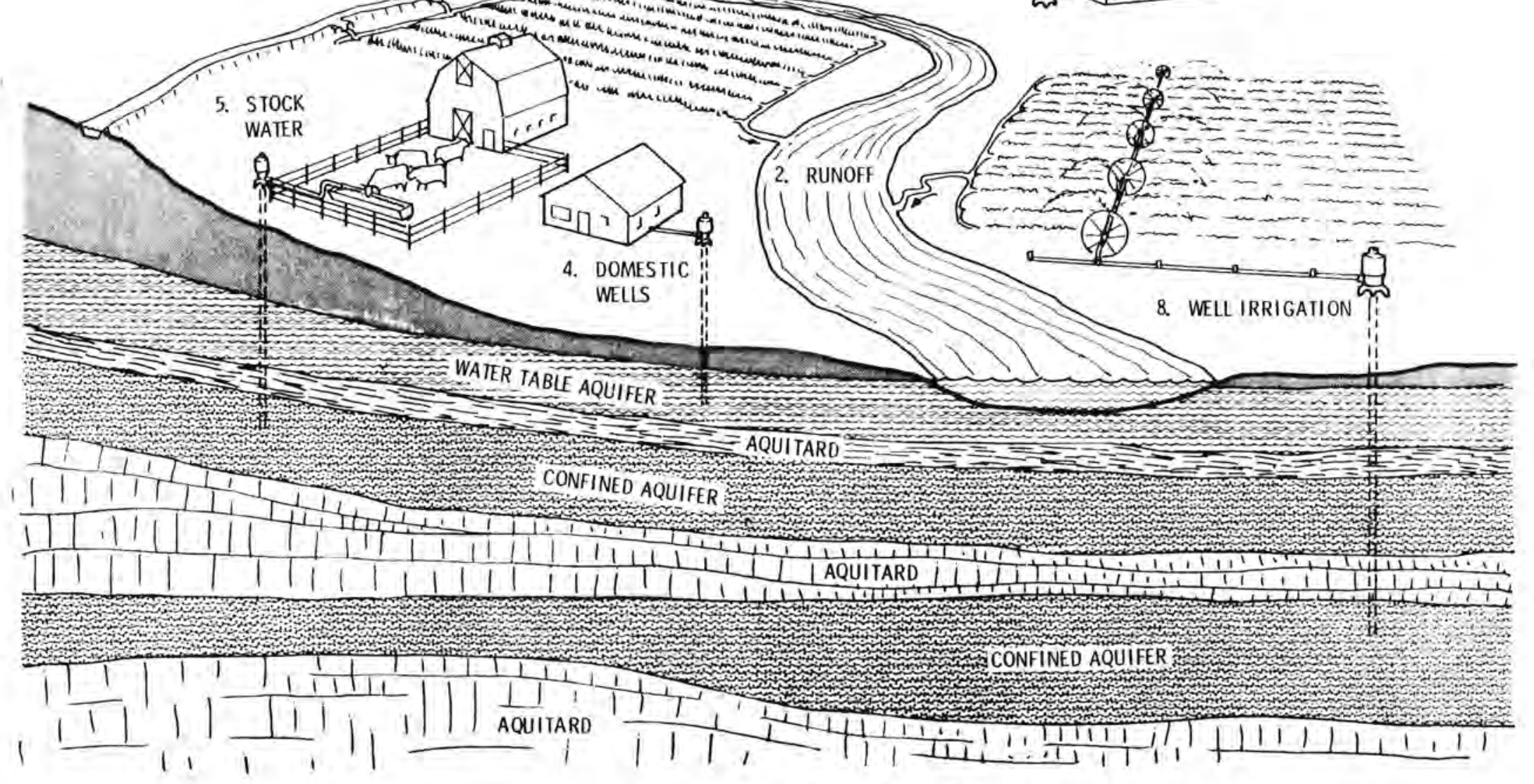

FIGURE 1. Nodal Recharge/Withdrawal Phenomena 
For numerical formulation, a horizontal $x-y$ coordinate grid system was adopted with uniform nodal spacing. $R$ represents the region of flow and $r_{i j}$ the sub-area associated with node ij (Figure 2).

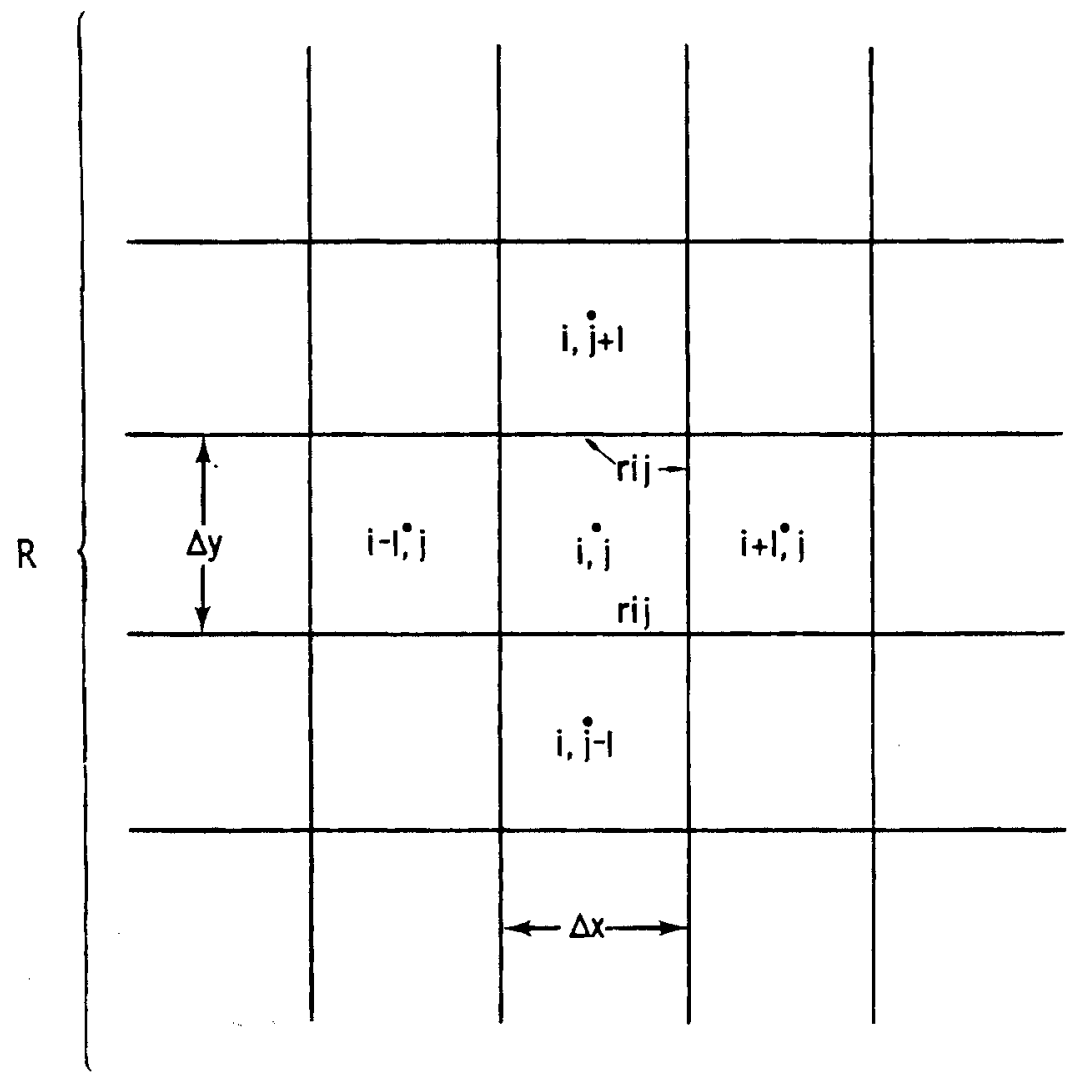

FIGURE 2. The Finite Difference Grid with the Nodal Numbering System

The differential equation, Equation 11, is then converted to finite difference form by integrating around the node area $r_{i j}$. Now:

$$
\int_{r} \int_{i j}\left[\underline{\nabla} \cdot K\left(h-h^{b}\right) \underline{\nabla h}-\phi \frac{\partial h}{\partial t}+N\right] d x d y=0
$$

By Green's theorem in the first form (Kellogg 1954): 


$$
\int_{r} \int_{i j \underline{\nabla}} \cdot k\left(h-h^{b}\right) \underline{\nabla h d x d y}=\oint_{\Gamma_{i j}}^{\oint} k\left(h-h^{b}\right) \frac{\partial h}{\partial n} d s
$$

where $n$ denotes the outward pointing normal to the curve $\Gamma$ which bounds the area $r_{i j}$. The line integral is taken in the anticlockwise direction. Using Equation 18, Equation 17 reduces to:

$$
\oint_{\Gamma_{i j}} k\left(h-h^{b}\right) \frac{\partial h}{\partial n} d s-\int_{r} \int_{i j}\left(n \frac{\partial h}{e}-N\right) d x d y=0
$$

In Figure 2 the corner points of the node area are at $(i-1 / 2, j-1 / 2)$, $(i+1 / 2, j-1 / 2),(i+1 / 2, j+1 / 2)$, and $(i-1 / 2, j+1 / 2)$. The area of $r_{i j}$ is $\Delta x \Delta y$. The integrals of Equation 19 are approximated as follows, with the integral along $\Gamma_{i j}$ divided into the integrals along the four sides of $r_{i j}:$

$$
\begin{aligned}
& \int_{i-1 / 2, j-1 / 2}^{i+1 / 2, j-1 / 2} K\left(h-h^{b}\right) \frac{\partial h}{\partial n} d x \simeq(K \Delta h)_{i, j-1 / 2} \frac{h_{i j}-h_{i, j-1}}{-\Delta y} \Delta x \\
& \int_{i+1 / 2, j-1 / 2}^{i+1 / 2, j+1 / 2} K\left(h-h^{b}\right) \frac{\partial h}{\partial n} d y \simeq(K \Delta h){ }_{i+1 / 2, j} \frac{h_{i+1, j}-h_{i j}}{\Delta x} \Delta y \\
& \int_{i+1 / 2, j+1 / 2}^{i-1 / 2, j+1 / 2} K\left(h-h^{b}\right) \frac{\partial h}{\partial n} d x \simeq(k \Delta h)_{i, j+1 / 2} \frac{h_{i, j+1}-h_{i j}}{\Delta y} \Delta x \\
& \int_{i-1 / 2, j+1 / 2}^{i-1 / 2, j-1 / 2} K\left(h-h^{b}\right) \frac{\partial h^{2}}{\partial n} d y \simeq(K \Delta h)_{i-1 / 2, j} \frac{h_{i j}-h_{i-1, j}}{-\Delta x} \Delta y \\
& \int_{r_{i j}} \int_{j}\left(+n \frac{\partial h}{\partial t}-N\right) d x d y \simeq n_{e i j} \frac{h_{i j}^{k}-h_{i j}^{k-1}}{\Delta t} \Delta x \Delta y-N_{i j} \Delta x \Delta y
\end{aligned}
$$

where the superscript $k$ denotes the iteration number 
and where the $K \Delta h$ half way between node center in the $j-1$ direction is

$$
\left(K_{\Delta} h\right)_{i, j-1 / 2}=1 / 2\left[K_{i j}\left(h_{i j}^{k}-h_{i j}^{b}\right)+k_{i, j-1}\left(h_{i, j-1}^{k}-h_{i j}^{b}\right)\right],
$$

A fully implicit representation of the time derivative has been used in Equation (20e). Combining the above approximations results in the finite difference approximation to the Boussinesq equation for a square grid system, $\Delta x=\Delta y$ :

$-(K \Delta h)_{i-1 / 2, j} h_{i-1, j}^{k}+\left[(K \Delta h)_{i-1 / 2, j}+(K \Delta h)_{i+1 / 2, j}+(K \Delta h)_{i, j-1 / 2}\right.$

$\left.+(K \Delta h)_{i, j+1 / 2}+n_{i j} \frac{(\Delta x)^{2}}{\Delta t}\right] h_{i j}^{k}-(K \Delta h)_{i+1 / 2, j} h_{i+1, j}^{k}$

$=(K \Delta h)_{i, j-1 / 2} h_{i, j-1}^{k}+(k \Delta h)_{i, j+1 / 2} h_{i, j+1}^{k}+n_{e_{j j}} \frac{(\Delta x)^{2}}{\Delta t} h_{i j}^{k-1}+N_{i j}^{k-1}(\Delta x)^{2}$

For node on boundaries along which the hydraulic potential is specified in time and space (and therefore no calculation is needed):

$$
h_{i j}^{k}=H_{i j}^{k}
$$

The impermeable boundaries of the region must be approximated in the grid system by shapes selected from figure 3. This avoids right angles which cause stagnation points and singularities in the mathematical solution of the ground-water flow equation. 


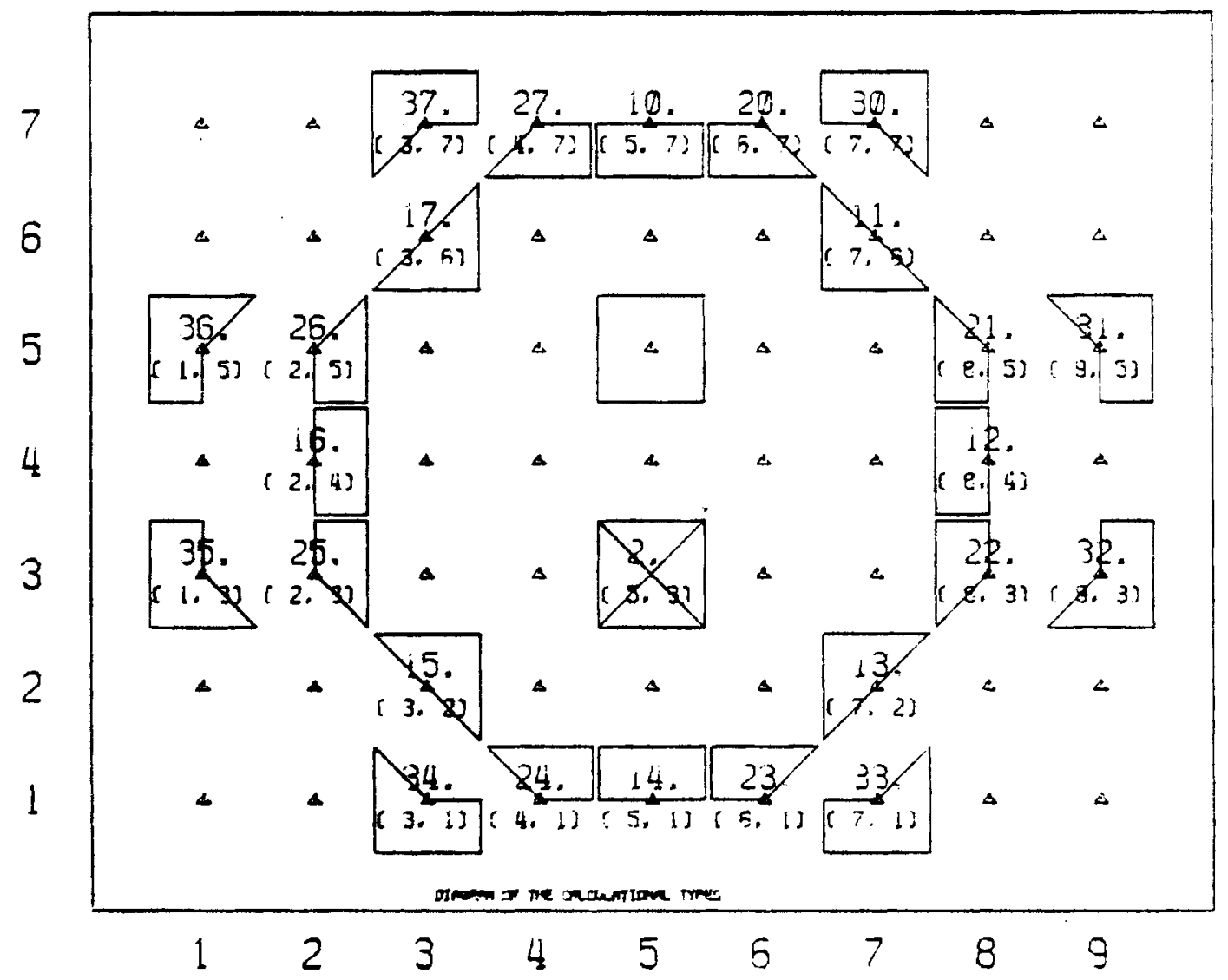

FIGURE 3. Schemat ic Showing Shapes and Rotation of Available Boundary Condition Types

The boundary conditions are put into finite difference form by applying the technique described above to a node area at the boundary of the region $R$. The boundary types are illustrated in figure 3 . The associated nodal area $r_{i j}$ can be either inside or outside the octagon. The finite difference equations are derived by setting the appropriate portions of the integral on $\Gamma_{i j}$ in Equation (18) to zero when the segment is impermeable, and by inputting $N_{i j}=N_{i j} n$ when the flux across the segment is specified. In finite difference form, 24 different equations correspond to each of the different boundary point subregions illustrated in Figure 3. Either a specified flux or no flow can be imposed by each of the 24 equations. The accretion term, whether infiltration or withdrawal, in finite difference form 
becomes $N_{i j}=q_{i j}(\Delta x)^{2}$ (units $L^{3} / T$ ) to be specified at each node.

Accretion at the fractional boundary nodes must have the nodal area properly reduced from $(\Delta x)^{2}$.

The partial differential equation and boundary conditions subsequently become a set of $\hat{N}$ finite difference equations, one for each node of the region $R$ being modeled. The boundary conditions have been effectively absorbed into the equations for their respective boundary nodes.

It should be noted that the finite difference equations can be derived in the same form by other techniques, such as Taylor series expansion. The equations for nodes on impermeable boundaries are equivalent to those obtained by introduction of a point external to the region for purposes of forming the normal derivative.

\section{Boundary Definitions}

To simulate the system, a model depends on segmenting the physical continuum into a discrete grid. Each grid segment is then represented by a single node within the model. The VTT Model uses a finite difference algorithm with a uniform grid and requires that each node within the Cartesian coordinate system be marked with a calculation type as:

- within the aquifer

- external to the aquifer

- a water or held potential boundary node $[h=H(x, y, t)]$

- an impermeable boundary for the aquifer with $q=0$ (aquifer boundary nodes, where the flux is known, are treated as the mathematical equivalent to an impermeable boundary node with the appropriate accretion term; i.e., $q \neq 0$ ).

To facilitate the marking of calculational boundary types to avoid right angles along no-flow boundaries, and to simplify representation of complex boundaries, a systematic method of representing interior, exterior, and boundary nodes was adopted. Figure 3 illustrates the different $k$ inds of nodal types used in the VTT code. There are basically four nodal types; others simply arise to handle the various shapes and orientations of the impermeable boundaries. 


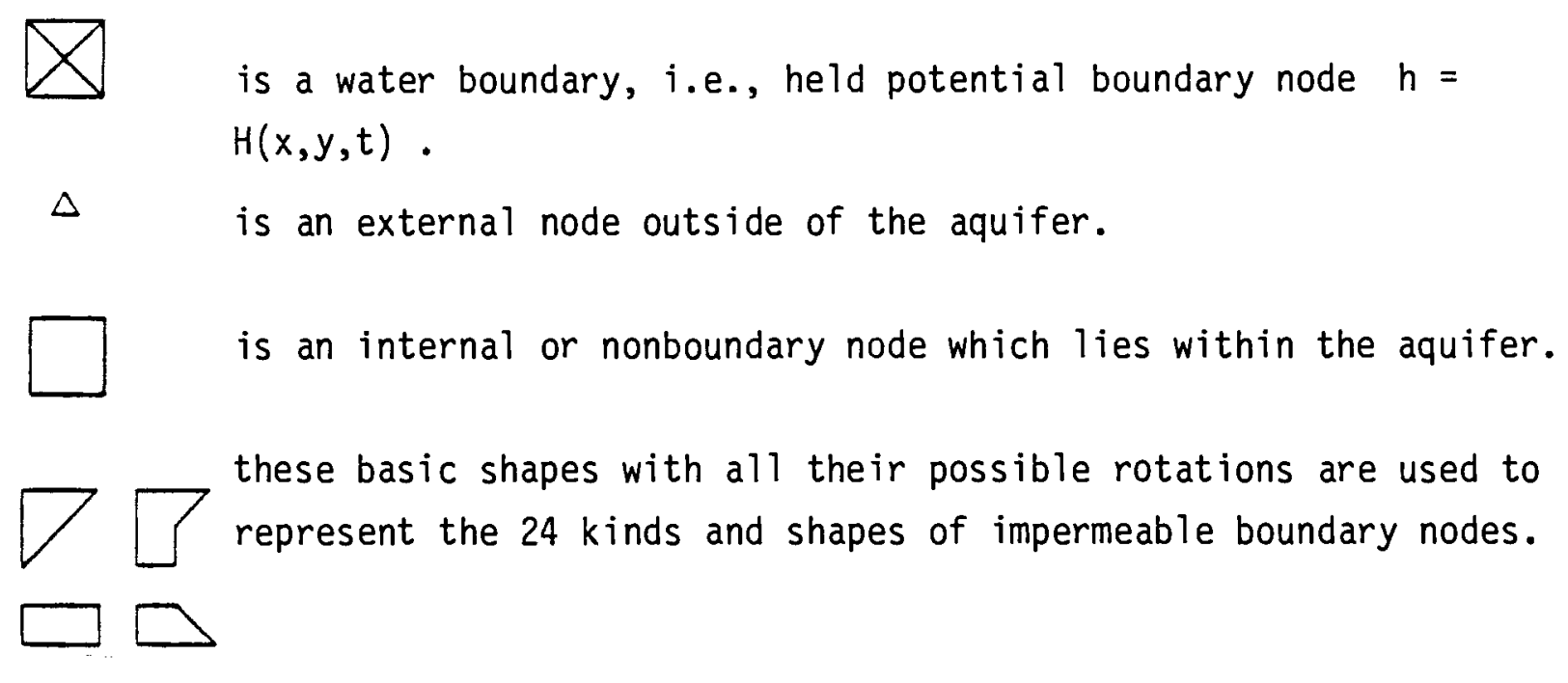

Solution Techniques

Three different solution techniques were selected to solve essentially the same set of equations, thus, resulting in three separate versions of the same model. Each of these is designed for use in specific problems. These will be described in general to avoid lengthy mathematical discussions.

The VTT version of the model solves the transient form of the system of finite different equations by using the successive line overrelaxation technique. For transient problems the solution is stable and convergent with sufficient speed to make solution of large matrices practical.

The VTTSS3 version of the model solves the steady-state system of finite difference equations resulting from the integration of Equation (17) when the transient term $n_{e} \frac{\partial h}{\partial t}$ is set to zero. This set of equations is solved by using a Newton iteration technique (Kellogg 1954). This version is primarily used for a system of aquifers in which one is unconfined and, therefore, the equations are nonlinear. Convergence of this method is quadratic in nature and for most ground water probiems the solution is reached in four to five iterations.

The VTTSSZ version of the model solves the same system of steady-state equations discussed in the preceding paragraph, except that it uses a Colesky decomposition method (Kellogg 1954). This version if used when all the aquifers being simulated are confined. This method is many times faster than the Newton version, and since the system of equations will be linear, no iteration is required. 


\section{REFERENCES}

1. Bear, Jacob. 1972. Dynamics of Fluids in Porous Media. American Elsevier: New York Publishing Co. Inc.

2. Kellogg, 0. D. 1954. Foundations of Potential Theory. Dover: New York.

3. Acton, Forman, S. 1970. Numerical Methods that Work. Harper and Row: New York. 


\section{DISTRIBUTION}

No. of

Copies

OFFSITE

A. A. Churm

DOE Chicago Patent Group

9800 South Cass Avenue

Argonne, IL 60439

27 DOE Technical Information Center

2 Argonne National Laboratory

Reference Library

9800 South Cass Avenue

Argonne, IL 60439

G. E. Barr

Div. 1141

Sandia Laboratories

Albuquerque, NM 87115

Batte lle Memorial Institute

Office of Nuclear Waste

Iso lat ion

Attn: Bever ly Rawles

505 King Avenue

Columbus, $\mathrm{OH} 43201$

John Bird

Geo logy Department

Corne 11 University

Ithaca, NY 14853

J. D. Bredehoeft

U.S. Geological Survey

Water Resources Divis ion

Reston, VA 22092

2 Brookhaven National Laboratory

Reference Section

Information Division

Upton, Long Is land, NY 11973
No. of

Copies

J. E. Campbe 11

Div. 54.3

Sandia Laboratories

Albuquerque, NM 87115

20 Wayne A. Carbiener

Office of Nuclear Waste

Isolation

Battelle Memorial Institute

505 King Avenue

Columbus, $\mathrm{OH} 43201$

H. C. Claiborne

Union Carbide Corp.

P.0. Box $Y$

Oak Ridge, TN 39380

Neville G. W. Cook

Dept. of Materials Science and Mineral Engineering

Hearst Mining Building

University of California

Berkeley, CA 94720

Carl R. Cooley

DOE Office of Waste Management

Washington, D. C. 20545

Jared Dav is

Nuclear Regulatory Commission

Washington, DC 20555

George DeBuchananne

U. S. Geolog ical Survey

Reston, VA 22092

R. T. Dillon

Div. 5413

Sandia Laboratories

Albuquerque, NM 87115 
No. of

Copies

J. 0. Duguid

Office of Nuclear Waste

I so lation

Battelle Memorial Institute

505 King Ave.

Columbus, $\mathrm{OH} 43201$

Environmental Protection Agency

Office of Radiation Programs

Technical Assessment Division AW559

Washington, DC 20460

Geraghty and Miller, Inc.

44 Sintsink Dr. East

Port Washington, NY 11050

Robert M. Garrells

Dept. of Geologic Sciences

Northwestern Univers ity

Princeton, NY 08540

W. G. Gray

Dept. of Civil Engineering

Princeton University

Princeton, NJ 08540

D. B. Grove

U.S. Geolog ical Survey

WRD

Mail Stop 413

Denver Federal Center

Denver, CO 80225

John Hand in, Director

Center for Tectomophysics

Texas A\&M University

College Station, TX 77840

Colin A. Heath

DOE Division of Waste Management

Washington, DC 20545

William M. Hewitt

Office of Nuclear Waste Isolation

Batte 1le Memorial Institute

505 King Avenue

Columbus, $\mathrm{OH} 43201$
No. of

Copies

Peter L. Hofmann

Office of Nuclear Waste Isolation

Battelle Memorial Institute

505 King Avenue

Columbus, $\mathrm{OH} 43201$

Muzaffer Kehnemuyi

Office of Nuclear Waste Isolation

Battelle Memorial Institute

$505 \mathrm{King}$ Avenue

Columbus, $\mathrm{OH} 43201$

John F. Kircher

Office of Nuclear Waste Isolation

Battelle Memorial Institute

$505 \mathrm{King}$ Avenue

Columbus, $\mathrm{OH} 43201$

Ronald B. Lantz

Inter-Environmental Consultants

11511 Katy Freeway

Houston, TX 77079

2 Lawrence Berkeley Laboratory

Reference Library

University of California

Berkeley, CA 94720

2 Lawrence Livermore Laboratory

Reference Library

P. 0. Box 808

Livermore, CA 94550

D. I. Leap

U.S. Geological Survey

Water Resources Division

MS 416

Denver Federal Center

Denver, CO 80225

S. E. Logan

Los Alamos Techn ical Associates, Inc.

P.0. Box 410

Los Alamos, NM 87544 
No. of

Copies

2 Los Alamos Scientific Laboratory

Reference Library

P.0. Box 1663

Los Alamos, NM 87544

John Lyons

Dept. of Earth Sciences

Dartmouth College

Hanover, NH 03755

R. D. MacNish

U.S. Geological Survey

Water Resources Div.

$301 \mathrm{~W}$. Congress

Tucson, AR 85701

J. B. Mart in

Asst. Director for Radioactive Waste Mgmt Branch

NRC Division of Materials and

Fuel Cycle Facility Licensing

Washington, DC 20555

John T. McGinn is

Office of Nuclear Waste

Isolation

Battelle Memorial Institute

505 King Avenue

Columbus, $\mathrm{OH} 43201$

She 1don Meyers

DOE Office of Nuclear Waste

Management

Washington, DC 20545

P. A. Mote

Bechtel Nationa1, Inc.

50 Beale St.

San Francisco, CA 94119

2 Barry Naft

NUS Corporation

4 Research Place

Rockville, MD 20805

T. N. Narasimhan

Lawrence Berkeley Laboratory

Berkeley, CA 94720
No. of

Copies

J. 0. Neff

Department of Energy

Columbus Program Office

505 King Avenue

Columbus, $\mathrm{OH} 43201$

2 Neil A. Norman

Environmental Sciences

Department

Bechtel National Inc.

P.0. Box 3965

San Francisco, CA 94105

2 Oak Ridge National Laboratory

Central Research Library

Document Reference Section

Oak Ridge, TN 37830

Frank L. Parker

Dept. of Environmental Eng.

Vanderbilt University

Nashville, TN 37235

L. W. Picking

Stone and Webster Eng. Corp.

245 Summer St.

Boston, MA 02107

George Pinder

Dept. of Civil Engineering

Princeton University

Princeton, NJ 08540

Gary Robb ins

U.S. Nuclear Regulatory Commission

Division of Waste Management

Washington, DC 20555

2 Savannah River Laboratory

Reference Library

Aiken, SC 29801

G. Sego1

Bechtel National, Inc.

50 Beale St.

San Francisco, CA 94119 
No. of

Copies

Raymond Siever

Dept. of Geological Sciences

Harvard University

Cambridge, MA 02138

Howard P. Stephens

Sandia Labor atories

P.0. Box 5800

Albuquerque, NM 87115

David B. Stewart

U.S. Geological Survey National Center 959

Reston, VA 22092

Lewis D. Thorson

Lawrence Livermore Laboratory

Box 803, L-224

Livermore, CA 94550

N. P. Timofeef

State University of New York

Binghampton, NY 13901

Wenda 1 Weart

Division 1140

Sandia Laboratories

Albuquerque, NM 87115

Robert Williams

Electric Power Research Inst. 3412 Hillview Avenue

P.0. Box 10412

Palo Alto, CA 94304

Paul A. Witherspoon

Lawrence Berkeley Laboratory

University of California

Berkeley, CA 94710

\section{FOREIGN}

D'Allessandro Avogadro

Commission of European

Commun ities

Joint Research Centre

I-21020 Ispra (Varese)

ITALY
No. of

Copies

V. K. Barwe 11

Environmental Research Branch

Atomic Energy of Canada, Ltd.

Chalk River, Ontario, KOJIJo

CANADA

Center for Atomic Energy

Documentation (2AED)

Attn: Dr. Bell

Postfach 3640

D-7500 Kar lsruhe

F.R. of GERMANY

J. A. Cherry

Dept. of Earth Sciences

Water loo, Ontario

CANADA

Ferruccio Gera

Radiation Protection and Waste Management Division

Nuclear Energy Agency/OECD

38 boulevard Suchet

75016 Paris

FRANCE

K. H. Hubentha 1

Bundesministerium fur Forschung und Technologie

Stressemannstrasse 2

Postfach 200706

D-5300 Bonn

F.R. Of GERMANY

2 INIS Clearinghouse

International Atomic Energy Agency

P.0. Box 590

A-1011, Vienna

AUSTRIA

Klaus Kuhn

Institute fur Tiefagerung

Wissenschaftliche Abteilung

Berliner Strasse 2

3392 Clausthal - Zellerfeld

F.R. Of GERMANY 
No. of

Copies

Hans W. Levi

Hahn-Meitner-Institut fur Kernforschung

Glienicker Strasse 100

1000 Ber 1 in 39

F.R. of GERMANY

Library

Studsvik Energiteknik $A B$

S-611 01 Nykoping

SWEDEN

Franz Peter Dester le

Physikalisch-Chemische Bundes ansta $1 t$

Bundesallee 100

D- 3300 Braunschweig

F.R. of GERMANY

Ton is Papp

Karnbrans lesakerhet

Fack. 10240

Stockho $1 \mathrm{~m}$

SWEDEN

Egbert Schapermeier

Battelle-Institute e.V.

Am Romerhof 35

D-6000 Frankfurt am Main 90

F.R. of GERMANY

Tjalle Vandergraff

Atomic Energy of Canada Limited

Whiteshe 11 Nuclear Research Establishment

P inawa, Manitoba ROE ILQ

CANADA

ONSITE

4 DOE Richland Operations Office

0. J. Elgert

H. E. Ransom

J. J. Schreiber

F. R. Standerfer
No. of

Copies

2 Rockwe 11 Hanford Operations

R. C. Arnett

R. A. Deju

Rockwe 11 Document Control

51 Pacific Northwest Laboratory

G. L. Benson

D. L. Bradley

A. Brandstetter (10)

R. W. Bond

J. S. Burlison

D. B. Cear lock

M. 0. Cloninger

C. R. Cole

F. H. Dove

D. W. Dragnich

D. R. Friedrichs

S. R. Gupta

M. A. Harwe 11

B. W. Howes

J. H. Jarrett

F. E. Kaszeta

M. R. Kreiter

J. S. Light

R. W. Nelson

A. M. Platt

J. R. Raymond (10)

A. E. Reisenauer

R. J. Serne

C. S. Simmons

J. K. Soldat

J. F. Washburn

Technical Information Library (5)

Publishing Coordination Ro (2)

Water and Land Resources

Department Library (10) 


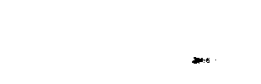


RECIPIENTS OF PNL-3160-1

If you wish to be on the distribution 1 ist for future model computer code and report revisions, please fill out the form below and return it to Dr. Alb in Brandstetter.

\section{REQUEST FOR MODEL REPORT REVISION}

Name

Title and Affiliation

Address

Date

Signature

Please fill out this form and mail to:

Dr. Albin Brandstetter

Project Manager, AEGIS

Battelle, Pac if ic Northwest Laboratory

P.0. Box 999

Richland, WA 99352

U.S.A. 


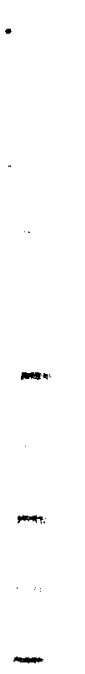

emane

$\checkmark$

m 